\title{
Zoon's Balanitis: Benign or Premalignant Lesion?
}

\author{
Nicola Balato Massimiliano Scalvenzi Serena La Bella \\ Luisa Di Costanzo
}

Department of Dermatology, University of Naples Federico II, Naples, Italy

\section{Key Words}

Balanitis · Squamous cell carcinoma $\cdot$ Skin inflammation

\begin{abstract}
Zoon's balanitis or balanitis circumscripta plasmacellularis is a chronic disease of unknown origin. This condition usually manifests in middle-aged or elderly uncircumcised men. Although of unknown etiology, different factors have been reported to be involved in its genesis (local infections, poor hygiene, heat, friction, and constant rubbing). It is generally considered to be a benign condition, and its association with malignancies has been rarely reported. We report the case of an uncircumcised man, who developed clinically and histopathologically evident squamous cell carcinoma of the penis in an area affected by Zoon's balanitis.
\end{abstract}

\section{Introduction}

Zoon's balanitis or balanitis circumscripta plasmacellularis is a benign chronic disease of unknown origin [1]. This condition usually manifests in middle-aged or elderly uncircumcised men. Zoon's balanitis, unlike some other inflammatory penile dermatoses, is generally not thought to be a precursor for neoplasia [2].

We herein report the case of an uncircumcised man, who developed clinically and histopathologically evident squamous cell carcinoma of the penis in an area affected by Zoon's balanitis.

\section{Case Report}

A 71-year-old uncircumcised man presented with a 3-month history of extremely painful genital sores associated with swollen foreskin and dysuria, not preceded by any flu-like symptoms. There was no history of any allergic reactions to drugs. The patient reported that he has suffered from Zoon's balanitis for 12 years, confirmed by a histopathological examination. He treated the condition with 
topical corticosteroids with relative improvement and paid periodic visits for 7 years; after that he stopped performing any follow-ups.

Clinical examination revealed a well-demarcated, highly indurated, glistening erythematous plaque (about $3 \mathrm{~cm}$ in diameter) on the glans and adjacent preputial mucosa. It bled easily on touch (fig. 1 ).

No inguinal lymphadenopathy was associated. A 3-mm punch biopsy of the glans was performed showing typical features of a moderately differentiated squamous cell carcinoma (nests of atypical cells with abundant eosinophilic cytoplasm and large vesicular nucleus) (ig. $2 a)$. A dense dermal inflammatory infiltrate, constituted predominantly by plasma cells, was also present in the specimen (fig. 2b, c). Therefore, a surgical excision of the lesion was performed.

\section{Discussion}

Zoon's balanitis is characterized by a solitary red-orange plaque of the glans and prepuce. Although the etiology is unknown, different factors have been reported to be involved in its genesis (local infections, poor hygiene, heat, friction, and constant rubbing) [2]. Histopathologic examination demonstrate an inflammatory infiltrate of predominantly plasma cells, atrophy of epidermis, spongiosis, tortuous dermal blood vessels, and exocytosis of inflammatory cells $[2,3]$.

It is generally considered to be a benign condition, and its association with malignancies has been rarely reported. In 1999, a case of penis carcinoma arising in a patient with Zoon's balanitis was described by Joshi [4], implying that this inflammatory lesion could be a premalignant condition or could contribute to the development of squamous cell carcinoma. After this report, the hypothesis that Zoon's balanitis may be followed by penile carcinoma or premalignant lesions started to arise [5]. In 2001, Bunker claimed that there were zoonoid changes in clinical and histological features in some cases of lichen sclerosus, lichen planus, Bowenoid papulosis and penile cancer. These zoonoid changes could suggest that Zoon's balanitis per se is a premalignant condition [6]. Recently, Starritt and Lee reported a case of erythroplasia of Queyrat of the glans on a background of Zoon's plasma cell balanitis [7].

The hypothesis of the possible association between Zoon's balanitis and penile cancer could also be linked to the concept of inflammation as a cofactor in carcinogenesis. In 1863 , Virchow noted a connection between inflammation and cancer and sustained that this link may have implications for cancer prevention and treatment [8].

Therefore, prevention of penis' carcinoma is possible, including early detection and relative treatment of risk factors (phimosis, inflammatory conditions, multiple sexual partners, and HPV infections) and precancerous lesions $[9,10]$.

This case highlights the importance of frequent follow-ups for Zoon's balanitis; topical treatment, such as corticosteroids and calcineurin inhibitors $[4,5,7]$, may be important to prevent the development of a secondary carcinoma. In case of resistance to topical treatments, circumcision should be recommended because it could be curative and also protective against penile carcinoma [9]. 


\begin{tabular}{c|l|l|l} 
Case Reports $h$ & $\begin{array}{l}\text { Case Rep Dermatol 2009;1:7-10 } \\
\text { D0I: } 10.1159 / 000210440\end{array}$ & Published online: May 26, 2009 & $\begin{array}{l}\text { O 2009 S. Karger AG, Basel } \\
\text { ISSN 1662-6567 } \\
\text { www.karger.com/cde }\end{array}$ \\
\hline
\end{tabular}

Fig. 1. Squamous cell carcinoma - erythematous, glistening, well-demarcated, highly indurated lesion on glans and prepuce.

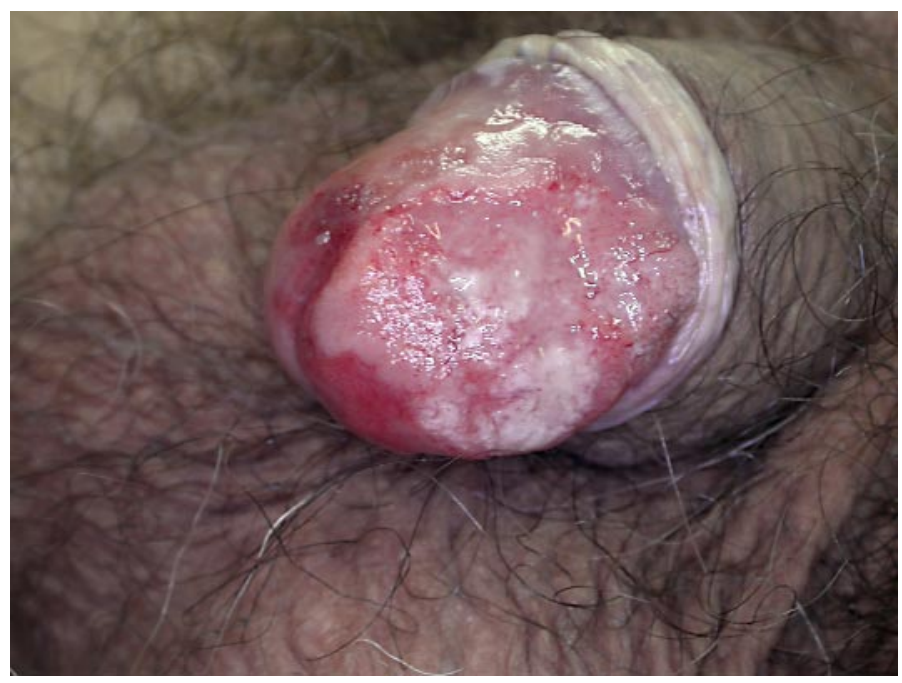

Fig. 2. a Penile surgical biopsy overview (haematoxylin and eosin; original magnification $\times 4$ ). b Nests of atypical cells scattered throughout the full thickness of the epidermis and infiltrating the dermis with mixed inflammatory infiltrate (haematoxylin and eosin; original magnification $\times 10$ ). $\mathbf{c}$ Dense dermal inflammatory infiltrate constituted predominantly by plasma cells (haematoxylin and eosin; original magnification $\times 40)$.

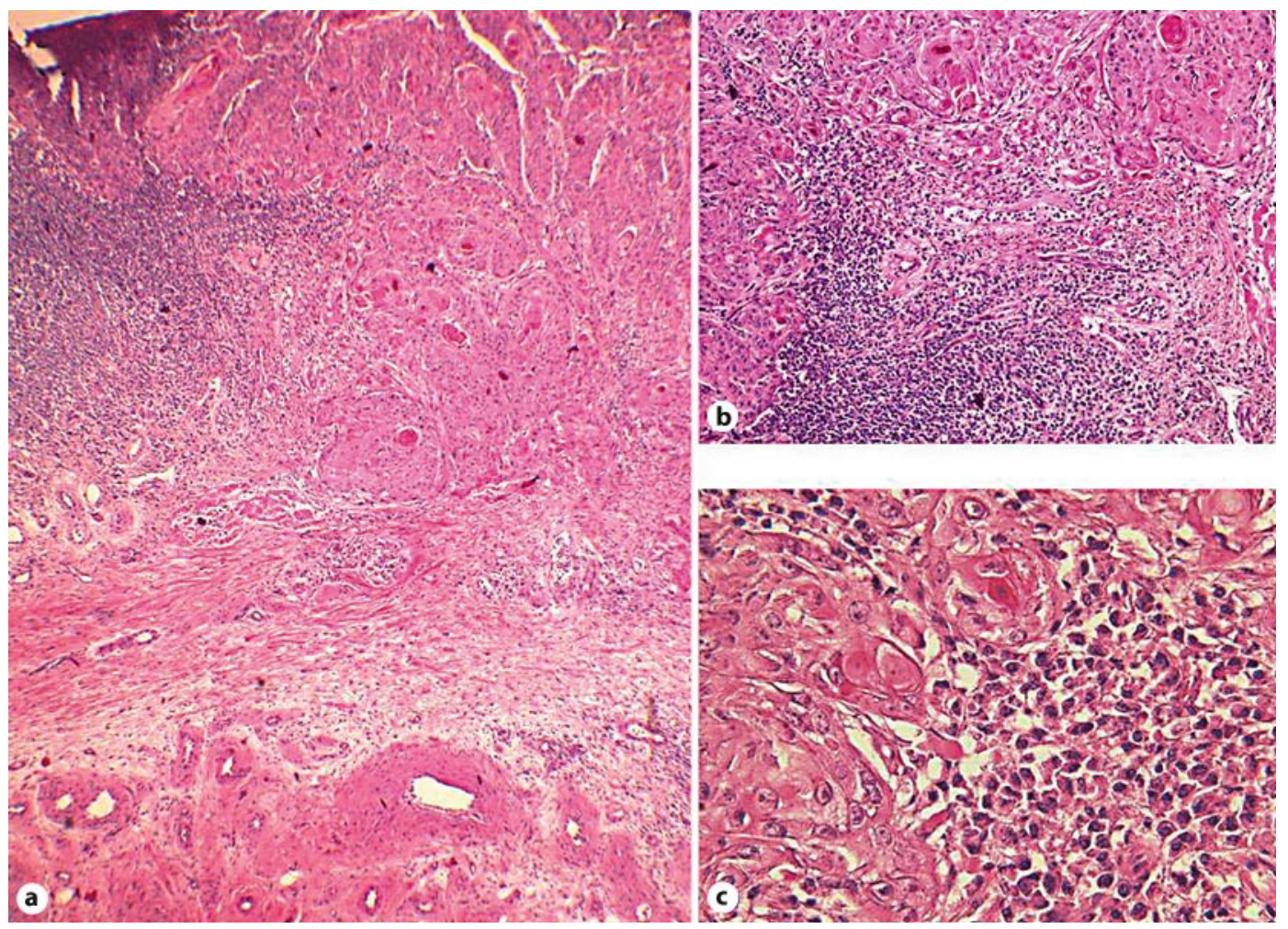




\section{References}

1 Zoon J: Balanoposthite chronique circonscrite bénigne à plasmocytes (contra érythroplasie de Queyrat). Dermatologica 1952;10:51-57.

2 Grosshans E: Malattie della mucosa genitale maschile e del pene; in Saurat JH, Grosshans E, Lauger P, Lachapelle JM (eds): Dermatologia e malattie sessualmente trasmesse. Milano, Masson S.p.A., 2000, p 836.

-3 Retamar RA, Kien MC, Chouela EN: Zoon's balanitis: presentation of 15 patients, five treated with a carbon dioxide laser. Int J Dermatol 2003;42:305-307.

4 Joshi UY: Carcinoma of the penis preceded by Zoon's balanitis. Int J STD AIDS 1999;10:823-825.

-5 Porter WM, Hawkins DA, Dinneen M, Bunker CB: Zoon's balanitis and carcinoma of the penis. Int J STD AIDS 2000;11:484-485.

-6 Bunker CB: Topics in penile dermatology. Clin Exp Dermatol 2001;26:469-479.

7 Starritt E, Lee S: Erythroplasia of Queyrat of the glans penis on a background of Zoon's plasma cell balanitis. Australas J Dermatol 2008;49:103-105.

8 Balkwill F, Mantovani A: Inflammation and cancer: back to Virchow? Lancet 2001;357:539-545.

9 Buechner SA: Common skin disorders of the penis. BJU Int 2002;90:498-506.

10 Tsen HF, Morgenstern H, Mack T, Peters RK: Risk factors for penile cancer: results of a population-based case-control study in Los Angeles County (United States). Cancer Causes Control 2001;12:267-277. 